Guiding Principles on Sanctuary Scholars in UK Higher Education

A document outlining guiding principles, which lay the

foundations for Sanctuary

Scholarship schemes
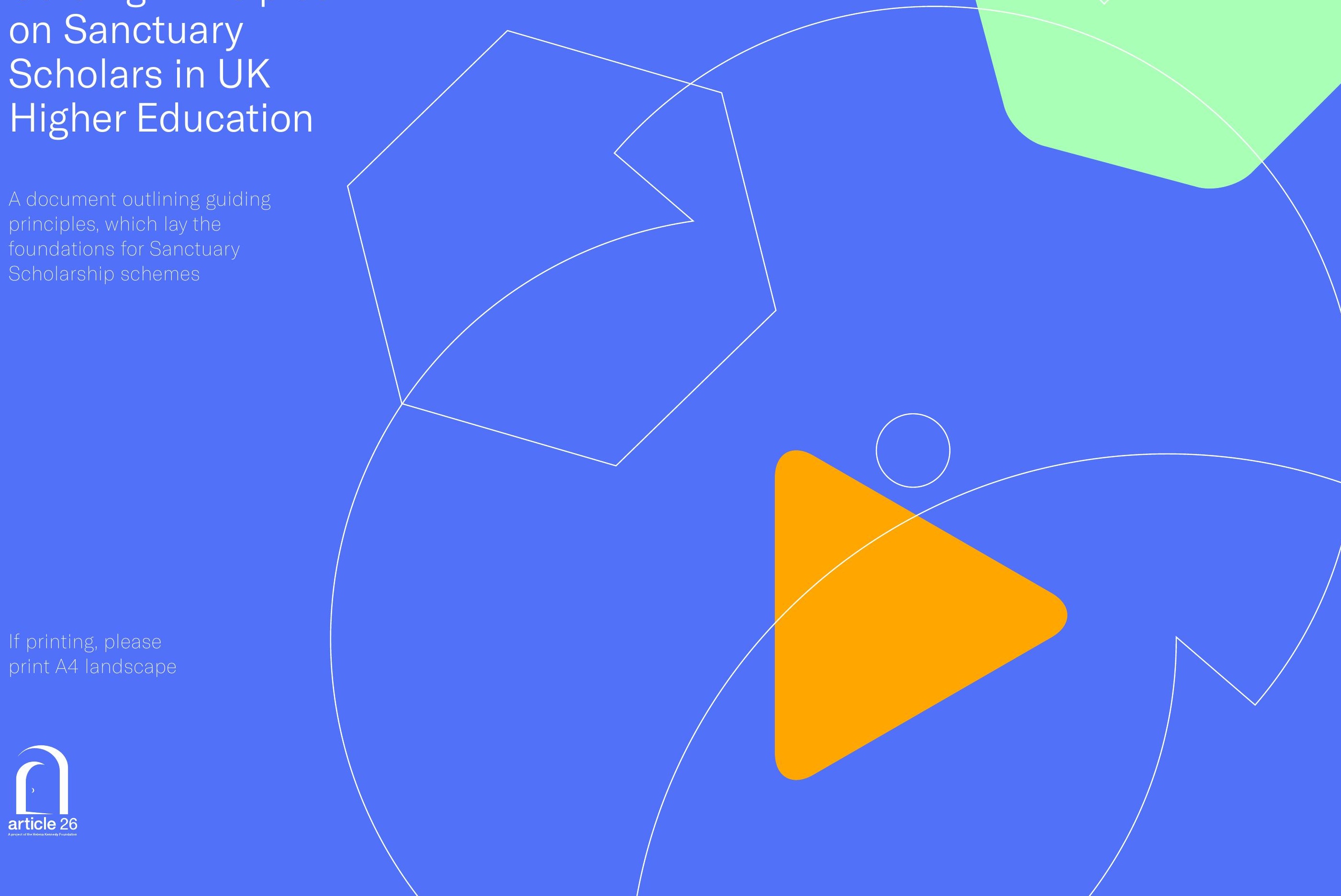


\section{Guiding Principles}

- a document outlining

guiding principles, which lay

the foundations for Sanctuary

Scholarship schemes.

\section{Contents}

Introduction

Part 1

Introduction - Scope and Purpose

8

Part 2

Section 1 - The Principles

10

Part 2

Section 2 -Adoption of The Principles

Guiding Principles On Sanctuary Scholars In UK Higher Education

Authored by

Ben Hudson, Lecturer in Law, University of Lincoln \& Rebecca Murray, Director of the Article 26 Project.

First published by Article 26 a project of the Helena Kennedy Foundation in January 2018. 
The 'Guiding Principles on Sanctuary Scholars in UK Higher Education' are a series of principles designed to respond to the specific needs of forced migrants who are undertaking, or seek to undertake higher education courses or programmes in the UK.

At their core, the Guiding Principles embody and reinforce a central aim of enabling, encouraging and supporting forced migrant students in UK higher education.

While recognising that many individuals experience barriers to accessing and succeeding in higher education, some of which are perhaps inherent to the UK higher education sector, it is evident that forced migrants face additional barriers that exist as a direct result of either their immigration statuses or their personal histories. It is these barriers that the Guiding Principles seek to address.

The Guiding Principles are primarily guidancegiving, and in this respect, are targeted especially towards higher education institutions (HEls), both those HEls that currently deliver specific educational opportunities for forced migrants and those HEls that are considering doing so in the future. The Guiding Principles intend to guide HEls in designing, administering and implementing educational opportunities for forced migrants, and also aim towards further uniting HEls through a series of commonly-agreed upon principles that underpin all such educational initiatives, whatever their substance.

The Guiding Principles aim to meet the need of HEls for overarching guidance that can be used to form the basis of educational initiatives targeted towards forced migrant students, and respond to a desire, expressed by forced migrants and many others, for greater consistency, coherency, accessibility and transparency across the sector. In this respect, the Guiding Principles are informed by extensive consultation with $\mathrm{HEI}$ representatives, academics, practitioners, and non-government organisations (NGOs) and charities, as well as with forced migrant students themselves.
Their formulation has greatly benefitted from insights gleaned from expert gatherings at conferences, symposia and working group meetings, for which the authors are hugely appreciative.

Although the Guiding Principles are specific and targeted to real and identified challenges, they are nevertheless broad in their formulation. This breadth is intentional, done so as to permit their wide application and use across the sector. The Guiding Principles are broad in three main ways.

First, the term 'forced migrant' is employed within the definition of a 'Sanctuary Scholar'. The reason for using this term, as opposed to any other, is itself three-fold:

- it reflects and encompasses the many diverse and complex immigration statuses that exist in respect to forced migration;

- it intends to transcend the numerous, often pejorative, stereotypes associated with such statuses; and

- the word 'forced' reflects the fact that the displacement experienced is due to events and circumstances beyond an individual's personal control.

Second, the Guiding Principles recognise that educational opportunities for forced migrants are broad in their design and in their substance. This is in itself a strength. The Guiding Principles therefore use the term 'Sanctuary Initiatives' as an overarching, catch-all term that is inclusive of this breadth and diversity of such initiatives.

Third, the Guiding Principles take into consideration all stages of the student lifecycle, interpreted broadly so as to include all interactions a forced migrant has with an $\mathrm{HEI}$. Application of the Principles is therefore not restricted to only a formal period of registration on a particular course or programme of study.
The Guiding Principles do not stand alone. They should be read in conjunction with other relate resources, as well as being read consistently with relevant legal provisions.

The following document is structured into two main parts. There is, first, an introduction to the Guiding Principles, before, second, the

Principles themselves, with the latter separated into two sections:

Part 1

Introduction - Scope and Purpose

The introduction to the Principles clearly identifies their scope and purpose. While its content is authoritative, the introduction does not constitute part of the Principles for the purposes of adoption. The introduction consists of five introductory paragraphs that concern the following:

1. Background, context and purpose

2. Defining the terms 'Sanctuary Scholar' and 'forced migrant' for the purposes of the Principles

3. Outlining the Principles' guidance-giving role

4. A statement of consistency with other

related guidance and relevant legal provisions

5. Dissemination, adoption and application of the Principles
Part 2

Section 1 - The Principles

The Principles are separated into two sections. The first section, which consists of ten Principles, concerns:

1. The right of forced migrants to access higher education

2. Equal treatment and non-discrimination

3. The right to privacy

4. An outline of Sanctuary Initiatives

5. Underlying principles for the design, administration and implementation of Sanctuary Initiatives

6. Selection processes and removal of procedural barriers

7. Communication

8. Academic, pastoral and professional support

9. Student progress and participation

10. Staff training

\section{Part 2}

Section 2 - Adoption of the Principles

The second section consists of two Principles that deal with adoption of the Guiding Principles. All HEls are invited and encouraged to adopt and apply the Guiding Principles, in their entirety. This invitation is extended to all HEls, whether they do or do not at present offer Sanctuary Initiatives. These two Principles include:

11. An invitation to HEls to adopt the Principles

12. Dissemination and reporting, and the development of an internal Sanctuary Initiatives Policy 


\section{Part 1 \\ Introduction - Scope and Purpose}

The Guiding Principles on Sanctuary Scholars in UK Higher Education (from hereon in referred to as "the Principles") address the specific needs of forced migrants who seek to access higher education in the United Kingdom of Great Britain and Northern Ireland (UK).

Such persons often suffer disadvantage and face seemingly insurmountable barriers in accessing higher education, whether this be, for example, due to their experiences as forced migrants, their immigration status in the UK, their English language abilities, or issues raised by their prior study.

The Principles recognise the crucial role that higher education institutions (HEls) can have in providing opportunities that enable and encourage forced migrants to access higher education in the UK, and provide a framework for HEls in the design and implementation of such initiatives.

2.

The term 'Sanctuary Scholar' is an umbrella term that refers to any forced migrant who is undertaking or seeks to undertake, a higher education course or programme in the UK. The term 'forced migrant' is used here to reflect the many diverse and complex legal immigration statuses that exist; it intends to encompass these statuses while also transcending the many, often pejorative, stereotypes associated with them. Further, the word 'forced' is used to reflect the fact that the displacement experienced by such persons is due to events and circumstances beyond their personal control.
For the purposes of the Principles, forced migrants are persons who, being present in the UK, are seeking or have sought international protection in the UK and are either awaiting a decision on their application for such protection or have been granted a form of status by the UK Home Office that permits their leave to remain in the UK, in particular:

a. Refugee status

i) A person who has been granted refugee status in the UK by the UK Home Office

ii) A person who has been granted refugee status outside the UK and has been resettled to the UK through a government-supported scheme.

b. Humanitarian Protection

i) A person who has been granted Humanitarian Protection in the UK by the UK Home Office

ii) A person who has been granted Humanitarian Protection outside the UK and has been resettled to the UK through a government-supported scheme

c. Indefinite Leave to Remain (ILR)

d. Limited Leave to Remain (formerly Discretionary Leave to Remain), granted in respect to a claim for asylum or an application made on human rights grounds.

e. Leave as an Unaccompanied AsylumSeeking Child (UASC leave)

This includes the spouse, civil partner or child of an asylum seeker whose claim is dependent upon the principal applicant. This also includes the spouse civil partner or child of a refugee or a person with Humanitarian Protection, if that relationship existed at the time of application for such protection; and may include the spouse, civil partner or child of a refugee or a person with Humanitarian Protection, if that relationship began after the time of application for such protection.
The Principles provide guidance to HEls and other education providers in designing, administering and implementing initiatives for Sanctuary Scholars. Nothing in the Principles is to be interpreted as restricting HEls from going beyond these here stated minimum standards in the measures they take in support of forced migrants.

The Principles are to be read in conjunction with the following resources:

-Who Needs to Comply?

- Sanctuary Scholars \& Compliance

- Identifying Sanctuary Scholars

- Reaching Out to Sanctuary Scholars

- Sanctuary Scholarship Application Form

- Selecting Sanctuary Scholars.

In addition to this series of guides, the Article 26 project has produced multiple sources of information that can be found under the 'Policy \& Resources' section of the Article 26 website (http://article26.hkf.org.uk).

The Principles shall also be read consistently with and without prejudice to relevant UK law, in particular, immigration law, equality law and data protection law; as well as relevant provisions of international law.
Unless otherwise stated, the Principles apply during all phases of the student lifecycle. In particular, the phrase 'during their studies' is to be interpreted as being inclusive of all interactions a forced migrant has with an HEl, whethe or not that interaction occurs during the formal period of registration on a course or programme of study. 


\section{Section 1 - The Principles}

\section{Principle 1}

\section{The right of forced migrants to access higher education}

11

Every human being has the right to education. As affirmed in Section 1(1)(b) of the Human Rights Act 1998 and Article 2 of the First Protocol to the Convention for the Protection of Human Rights and Fundamental Freedoms (European Convention on Human Rights), no person shall be denied the right to education.

$$
1.2
$$

In accordance with Article 13(2)(c) of the United Nations International Covenant on Economic Social and Cultural Rights, higher education shall be made equally accessible to all, on the basis of capacity.

$$
1.3
$$

All forced migrants in the UK have the right to access higher education, in full equality with all other persons in the UK. They shall not be discriminated against in the enjoyment of this right on the ground that they are forced migrants.

\section{Principle 2}

\section{Equal treatment and \\ non-discrimination}

HEls shall recognise that Sanctuary Scholars are, first and foremost, students. As such, Sanctuary Scholars shall be treated equally to all other students, as far as it is appropriate and practicable to do so.

\section{2}

The preceding paragraph is without prejudice to the specific needs that such students may have on account of being forced migrants.

\section{3}

Sanctuary Scholars shall not be discriminated against at any time during their studies on the ground that they are forced migrants. Any such discrimination, should it occur, shall be treated by HEls with the utmost severity and be appropriately dealt with without delay.

\section{Principle 3}

\section{The right to privacy}

3.1

HEls shall respect the right to privacy of each Sanctuary Scholar.

\section{2}

The sensitive personal data, which for the purposes of the Principles additionally includes information as to name or immigration status,

of a Sanctuary Scholar shall not be disclosed to any external party unless required by law, and in strict accordance with the Data Protection Act 1998 and other relevant legislation.

\section{3}

The preceding paragraphs shall not be interpreted as an interference with the legal responsibilities of HEls in respect to the wider authorities in the UK.
Principle 4

\section{An outline of Sanctuary Initiatives}

4.1

HEls shall endeavour, within the means available to them, to provide opportunities for Sanctuary Scholars to access higher education. This can be achieved in diverse ways, but may likely

include initiatives (from hereon in referred to as

"Sanctuary Initiatives") such as:

a. Bespoke scholarship schemes that are tailored to the needs of Sanctuary Scholars (commonly referred to as "Sanctuary Scholarships").

b. Bespoke educational initiatives that are tailored to the needs of Sanctuary Scholars.

c. Tuition fee waivers issued to Sanctuary Scholars for their chosen course or programme of study.

d. Access to dedicated bursaries that support Sanctuary Scholars in meeting accommodation costs, living costs, educational costs, or similar.

e. Making available to Sanctuary Scholars existing funding streams and bursaries for which they are not currently eligible. This may include international hardship funds, or similar, if Sanctuary Scholars are categorised by an $\mathrm{HEl}$ as international students for fee purposes; or general widening participation funds, or similar, if Sanctuary Scholars are categorised by an $\mathrm{HEl}$ as home students for fee purposes.

f. In-kind support, such as university accommodation or a pre-payment card to spend on university services, such as catering, or similar.

4.2

Sanctuary Initiatives are to be understood as constituting a form of positive action within the meaning of Chapter 2 of the Equality Act 2010. 


\section{Principle 5}

\section{Underlying principles for the design, administration and \\ implementation of \\ Sanctuary Initiatives}

5.1

When designing, administering and

implementing Sanctuary Initiatives, HEls shall:

a. Do so in a manner that is consistent with the abovementioned Principles 1-3.

b. Do so in a manner that is accessible, fair, inclusive and transparent, as far as it is possible to do so given existing challenges inherent within the UK higher education sector.

c. Give due consideration to the economic, financial, social and psychological needs of Sanctuary Scholars throughout the entire duration of their chosen course or programme of study.

d. Give due consideration to the academic interests of Sanctuary Scholars by endeavouring to avoid the establishment of Sanctuary Initiatives that arbitrarily limit student choice.

e. Take steps towards embedding and ensuring the sustainability of such initiatives.

\section{2}

The preceding paragraph shall be interpreted in a manner that respects the discretionary nature of Sanctuary Initiatives.

\section{Principle 6}

\section{Selection processes and removal of procedural barriers}

6.1

HEls shall be alert to the challenges that Sanctuary Scholars face on account of, in particular, their immigration statuses and personal histories. In this respect, HEls shall take every appropriate step to ensure that their relevant processes and procedures do not exacerbate such challenges or cause any additional difficulties for Sanctuary Scholars. Specifically, HEls shall work towards removing all barriers that may impede the ability or capacity of Sanctuary Scholars to begin, continue or complete their studies, as far as it is practicable to do so.

6.2

HEls shall conduct an annual review of all their relevant processes and procedures to identify the potential for any such issues, and take preventive steps to mitigate against these, as necessary, in a timely manner.

6.3

Selection processes associated with Sanctuary Initiatives shall be designed and administered in a manner that is consistent with Principle 5 above, and with the 'Selecting Sanctuary Scholars' guide In particular:

a. Selection processes shall be designed to accommodate the specific needs of Sanctuary Scholars. Specifically, HEls shall:

i) Take reasonable steps to enable the participation of Sanctuary Scholars.

ii) Make special efforts to overcome the detrimental effect of obstacles commonly experienced by Sanctuary Scholars when attempting to access higher education. b. Eligibility criteria and selection criteria shall be made clear, transparent and accessible to all intended audiences.

c. Selection decisions shall be made and communicated without any unnecessary delay.

d. Any reserve list process shall be administered with sensitivity, clarity and an appropriate degree of transparency.

e. Any conditions attached to an offer must be reasonable, and shall be communicated explicitly and with clarity.

6.4

It is not the role or responsibility of HEls to attempt to predict, assess or determine the relative success of an individual's application for international protection. As such, the nature and stage of an applicant's immigration claim, or the duration of their leave, shall not normally affect their eligibility for Sanctuary Initiatives or be detrimental to their chances of success, either during the selection process or while on their chosen course or programme of study. Any decision to reject an applicant or to deregister an existing Sanctuary Scholar on such grounds shall only be made when it is in the best interests of the applicant or student, and when it is reasonable to assume that their current situation is likely to fatally jeopardise their ability to participate on their chosen course or programme of study. 


\section{Part 2}

\section{Section 1 - The Principles}

\section{Principle 7}

\section{Communication}

All internal and external communications in respect to Sanctuary Initiatives shall be managed in a clear and efficient manner. HEls shall consider establishing a dedicated first point of contact for all enquiries related to their Sanctuary Initiatives.

\section{Principle 8}

\section{Academic, pastoral and professional support}

8.1

All Sanctuary Scholars shall have access to appropriate and comprehensive support during their studies, in particular, academic, pastora and professional support. Due consideration shall be given to the specific and individual needs of each Sanctuary Scholar.

8.2

If the needed support does not already exist in-house, HEls shall consider either establishing such support mechanisms in-house or liaising with relevant external experts, in particular, government services, charities and other nongovernmental organisations.

8.3

HEls shall consider establishing an enhanced mitigating circumstances procedure that can be accessed by Sanctuary Scholars should their studies be affected by conditions or circumstances related to their immigration status.

HEls shall conduct an institution-wide review of their support mechanisms for Sanctuary Scholars on an annual basis.

\section{Principle 9}

\section{Student progress}

and participation

9.1

HEls shall make special efforts to:

a. Monitor the progress and wellbeing of Sanctuary Scholars.

b. Enable and encourage Sanctuary Scholar to fully participate in the academic and socia communities of the HEI.

\section{2}

Any such efforts made for the purposes

prescribed in the preceding paragraph shall not be intrusive and shall respect the right to privacy as provided for in Principle 3 above.
Principle 10

\section{Staff training}

Appropriate training shall be provided to all $\mathrm{HE}$ staff and associated personnel who during the course of their work interact with Sanctuary Scholars. The extent and content of such

training will depend on the level of interaction that a particular individual has with Sanctuary Scholars and in what capacity.

Such training shall be delivered in a manner that at all times respects the right to privacy as provided for in Principle 3 above. 


\section{Part 2}

Section 2 - Adoption of the Principles

\section{Principle 11}

\section{Adoption}

11.1

HEls are invited to adopt the Principles, in

their entirety, and to apply these when

developing, administering and implementing

Sanctuary Initiatives.

11.2

To indicate adoption of the Principles, an

appropriate $\mathrm{HEl}$ representative shall send a

notification of adoption to the Article 26 project.

\section{Principle 12}

\section{Dissemination, reporting and}

policy development

Upon adoption of the Principles, HEls are encouraged to:

a. Disseminate the Principles widely throughout their institution, ensuring, in particular, that all HEl staff and associated personnel who

interact with Sanctuary Scholars during the course of their work are provided with a copy of the Principles.

b. Develop and adopt an internal Sanctuary Initiatives Policy that is consistent with the Principles.

c. Submit to the Article 26 project a brief report, on an annual basis, that provides an overview of how the Principles are being applied at their institution.

d. Communicate to the Article 26 project any observations in respect to the application of the Principles. 
